\title{
Influence of season of birth on onset of gonadotrophic and ovarian functions in young doe hares (Lepus europaeus)
}

\author{
M. Caillol ${ }^{1}$, M. Mondain-Monval ${ }^{2}$, M. Meunier ${ }^{3}$ and B. Rossano ${ }^{1}$ \\ ${ }^{1}$ Laboratoire de Physiologie Sensorielle, Institut National de la Recherche Agronomique, F-78352 \\ Jouy-en-Josas Cedex, France; ${ }^{2}$ Fondation de Recherche en Hormonologie, 67-77 boulevard Pasteur, \\ F-94260 Fresnes, France; and ${ }^{3}$ Laboratoire de Neurobiologie de la Reproduction, Institut National \\ de la Recherche Agronomique, F-78352 Jouy-en-Josas Cedex, France
}

\begin{abstract}
Summary. The pituitary and ovarian responses to a monthly i.v. injection of $5 \mu \mathrm{g}$ luteinizing-hormone-releasing hormone (LHRH) were studied in three groups of young doe hares, born in January-February (group I), in April (group II) or at the end of the breeding season (August-September, group III). The LHRH injection was always followed by a release of $\mathrm{LH}$ and progesterone, which did not differ among the three groups at 3 months of age. The pituitary and ovarian responses to LHRH increased gradually from the age of 3 months in groups I and III and from the age of 9 months in group II. One female of the ten born in January-February ovulated and reached puberty in June, at the age of 4 months, but with a weak pituitary response. The females born in April displayed a seasonally delayed puberty, at 9 months of age (two of five females ovulated in the next January). Four of the five females born at the end of the breeding season ovulated after LHRH when 5 months old (in February), with a full pituitary-ovarian response. The low pituitary response of group I in JuneAugust, even if $10-20 \%$ of females ovulated after LHRH, suggests a need for a period of short days. Then, the most favourable conditions for the hare to reach puberty would be a period of short decreasing daylengths during the fall, followed by increasing daylengths after the winter solstice.
\end{abstract}

Keywords: brown hare; season of birth; puberty; LHRH; LH; progesterone; ovulation

\section{Introduction}

Doe hares (Lepus europaeus) are seasonal polyoestrous induced ovulators. In captivity, as in the field, the first parturitions occur in mid-January and the last ones in mid-October (Hewson, 1964; Raczynski, 1964; Martinet et al., 1970; Lincoln, 1974). The young hares reach adult body size at 4 months old and the growth rate is similar whatever the season of birth (Lincoln, 1974; Lincoln \& McKinnon, 1976). However, because of the duration of the breeding season, adult size can be reached from May to December, under long or decreasing short daylengths. Some preliminary data have shown that the young born before mid-March can reach puberty in August, at the end of the reproductive season, whereas those born during the second part of the breeding season reach puberty only at the beginning of the next reproductive season (Lincoln, 1974; Lincoln \& McKinnon, 1976; Louzis, 1976). However, no precise data are available on the relationships between the season of birth, the age at puberty and the endocrine factors associated with sexual maturation in the young doe hare.

The influence of the season of birth on the onset of gonadotrophic and ovarian functions was determined in young doe hares by studying the pituitary and the ovarian responses to a monthly i.v. injection of luteinizing-hormone-releasing hormone (LHRH), and a gonadotrophic response sufficient to induce ovulation was considered an indication of sexual maturity. 


\section{Materials and Methods}

\section{Animals and sampling}

Female hares were born in captivity and kept isolated outdoors at weaning ( 1 month). They were fed ad libitum with rabbit pellets, hay and water.

When 3 months old, ten females born in January-February (group I), five females born in April (group II), and five females born at the end of the breeding season (23 August-16 September, group III) received a single i.v. injection of $5 \mu \mathrm{g}$ LHRH every month $\left(1.7 \mu \mathrm{g} \mathrm{kg}^{-1}\right.$ body weight; Stimu-LH: Roussel, Paris, France).

The release of LH following LHRH administration was measured in serum sampled before injection, and 15,30 , $60,90,120,300 \mathrm{~min}$ and $24 \mathrm{~h}$ after injection.

The ovarian response to the LH peak was estimated by the acute secretion of progesterone measured in the same serum samples, by the determination of ovulation and the secretion of progesterone by the newly induced corpora lutea. A laparotomy under thiopentone sodium anaesthesia $\left(0.02 \mathrm{~g} \mathrm{~kg}^{-1}\right.$ body weight) was therefore performed the day after LHRH injection. When ovulation occurred, the secretion of progesterone by the newly induced corpora lutea was measured.

\section{Hormone assays}

Luteinizing hormone. Luteinizing hormone (LH) was measured as described by Mondain-Monval et al. (1985), using a rabbit anti-ovine LH antiserum kindly supplied by G. D. Niswender (GDN 15), a highly purified ovine LH (LER 1056-C2) labelled with $\mathrm{I}^{125}$ as a tracer and a canine LH (LER 1685-1) as a standard, both provided by L. E. Reichert. The sensitivity of the $\mathrm{LH}$ assay was $0.4 \mathrm{ng} \mathrm{ml}^{-1}$, and intra- and interassay coefficients of variation were 4 and $6 \%$, respectively.

Progesterone. Progesterone was measured according to Caillol \& Martinet (1976). Progesterone was purchased from Steraloids (Wilton, NH 03086, USA); $\left[1,2,6,7-{ }^{3} \mathrm{H}\right]$ progesterone was obtained from the C.E.A. (Saclay, France). The assay was performed after hexane extraction (Merck analytical-grade). The antiserum was highly specific, the major crossreactions were $7 \cdot 5 \%$ with deoxycorticosterone and $5 \alpha$-pregnane-3,20-dione. Blank values, run with each assay, were below the sensitivity of the assay ( $25 \mathrm{pg}$ for the standard curve, $2.5 \mathrm{ng} \mathrm{ml} \mathrm{m}^{-1}$ serum). Intra- and interassay coefficients of variation were $7 \cdot 0$ and $8.5 \%$, respectively.

\section{Statistical analysis}

The pituitary and the ovarian responses to LHRH were estimated by the total amount of LH and progesterone released in the $24 \mathrm{~h}$ after LHRH injection calculated from the sum of the concentrations found at the eight sampling times. These amounts were shown to vary like the area under the secretion curve and represented a global pituitary or ovarian response better than a peak value. Within each group of females, the effects of age and season on the onset of the pituitary and ovarian responses to LHRH were tested after logarithmic transformation of data by analysis of variance for repeated measures. Total amounts of $\mathrm{LH}$ and progesterone secreted after LHRH injection were compared for females either at the same age or at the same period of the year by one-way analysis of variance followed by the Duncan test (SAS, 1987).

\section{Results}

Whatever the period of the year and the age of the females, LH and progesterone could not be detected before LHRH injection; LHRH injection was always followed by a release of LH and progesterone which was similar in the three groups of 3-month-old females (Fig. 1).

\section{Age of females, season of birth and pituitary response to LHRH}

In females born in January-February (group I), the total amount of LH released increased progressively between 3 and 6 months, from April-May to July-August $\left(29.6 \pm 4.7 \mathrm{ng} \mathrm{ml}^{-1}\right.$ up to $77.6 \pm 19.9 \mathrm{ng} \mathrm{ml}^{-1}, P=0 \cdot 10$ ) (Fig. 1).

In females born in April (group II), the total amount of LH released remained very low from July to the beginning of September (3-5-month-old females) and increased significantly in January, when the females were 9 months old $(P<0.01)$. 
(a)
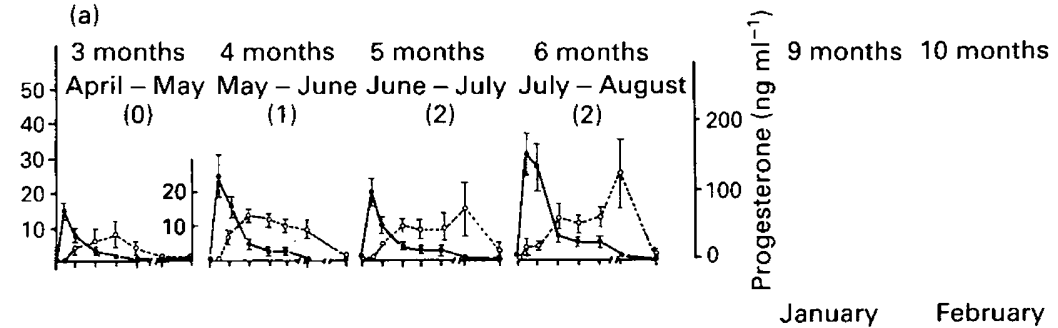

(2)

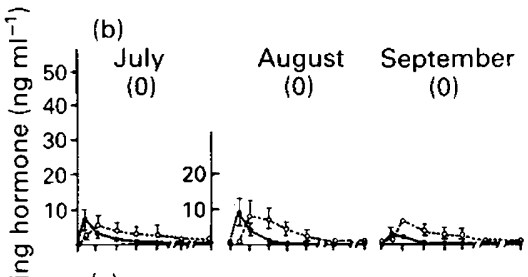

(c)

Decer

(0)

January

(0)

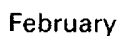

(4)

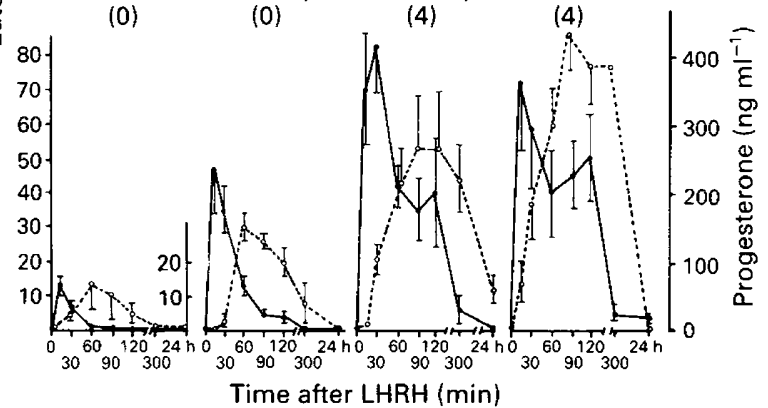

March

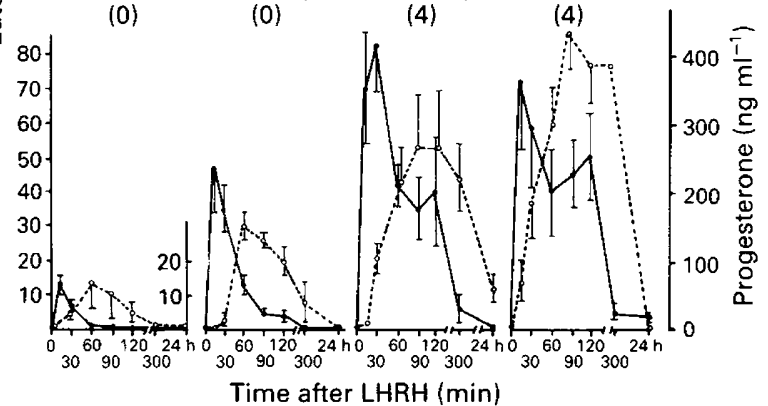

(4)

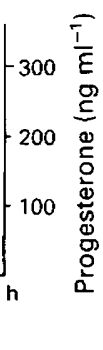

Fig. 1. Changes of luteinizing hormone $(\mathrm{LH}, \mathrm{O})$ and progesterone $(\mathrm{O})$ profiles after an i.v. injection of $5 \mu \mathrm{g}$ luteinizing-hormone-releasing hormone (LHRH) between 3 and 10 months in young female hares born (a) in January-February (group I, $n=10$ ), (b) in April (group II, $n=5$ ), and (c) in August-September (group III, $n=5$ ). Values are means \pm SEM. The number of ovulating females is indicated in parentheses. NB: Note the different scale for progesterone concentrations in 3-month-old females.

In females born at the end of the breeding season (group III), the pituitary response, which was very low in December (26.94 $\left.\pm 4.13 \mathrm{ng} \mathrm{ml}^{-1}\right)$, increased significantly in January and February, when the females were 4 months old $(P<0 \cdot 01)$.

From February onwards, a prolonged secretion of LH was observed, with high concentrations $2 \mathrm{~h}$ after LHRH injection.

The comparison between the three groups showed that the increase in LH release between 4 and 6 months was highest in group III $(P<0 \cdot 01)$.

\section{Age of females, season of birth and ovarian response to LHRH}

Acute secretion of progesterone. In females born in January-February (group I), the total amount of progesterone released increased significantly between 3 and 4 months $\left(33.6 \pm 14.8 \mathrm{ng} \mathrm{ml}^{-1}\right.$ versus $260.8 \pm 69.6 \mathrm{ng} \mathrm{ml}^{-1}, P<0.01$ ) and did not vary thereafter (Fig. 1).

In females born in April (group II), the total amount of progesterone released was very low from July to September and increased significantly in January, for 9-month-old females.

In females born at the end of the breeding season (group III), the acute secretion of progesterone, which was low in December, increased in January and again in February, from 4 months of age $(P<0.01)$. 
The comparison between the three groups showed that, between 3 and 6 months, the increase in progesterone release after LHRH was maximum in group III $(P<0.01)$.

Ovulation. A small proportion of young females born in January-February ovulated after LHRH injection at the end of the breeding season (1:10 at 4 months; 2:10 at 5 months). Females born later during the breeding season did not ovulate until January, at the age of 9 months for group II (2:5), or until February, at the age of 5 months for group III (4:5) (Fig. 1).

The total amount of LH and progesterone released after LHRH was significantly higher in ovulating than in non-ovulating females only when they are 4 to 5 months old (group $I$ in June-August, and group III in January-February) (Table 1).

Table 1. Number of ovulating doe hares and total amount ( $\left.\mathrm{ng} \mathrm{ml}^{-1}\right)$ of luteinizing hormone (LH) and progesterone (P) secreted in the $24 \mathrm{~h}$ after injection of LH-releasing hormone (LHRH) in ovulating and non-ovulating females

\begin{tabular}{lccc}
\hline & Group I & Group II & Group III \\
\hline Period of LHRH injection & June-August & January-February & January-February \\
Age of females & $4-6$ months & $9-10$ months & $4-5$ months \\
$\begin{array}{l}\text { Ovulating females } \\
\text { Non-ovulating females }\end{array}$ & 5 & 6 & 4 \\
LH & 14 & 4 & 6 \\
$\quad$ ovulating & $96 \pm 13^{* *}$ & $156 \pm 39$ & $302 \pm 65^{*}$ \\
non-ovulating & $35 \pm 7$ & $78 \pm 13$ & $122 \pm 20$ \\
$\quad$ ovulating & & & $1320 \pm 316^{*}$ \\
non-ovulating & $942 \pm 121^{* *}$ & $1029 \pm 194$ & $444 \pm 33$ \\
\hline
\end{tabular}

Significant difference between ovulating and non-ovulating doe hares $\left({ }^{*} P<0.05\right.$, $* * P<0.01)$.

Pseudopregnancy. When a pseudopregnancy was induced by LHRH injection, the onset of progesterone secretion was similar in group I in June-August and in groups II and III in January-February (Fig. 2).
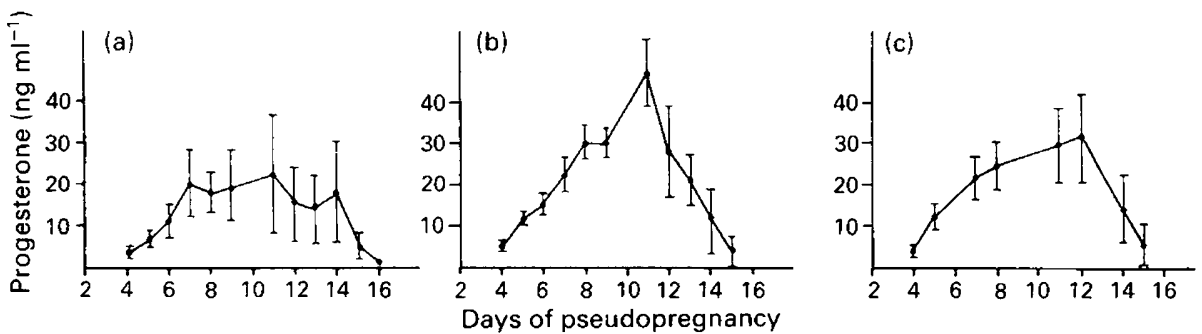

Fig. 2. Progesterone concentrations during pseudopregnancy induced by luteinizinghormone-releasing hormone (LHRH) injection (a) in June-August for group I hares born in January-February $(n=5)$, (b) in January-February for group II females born in April $(n=6)$, and (c) in February for group III females born in August-September $(n=4)$. Values are means \pm SEM for the number of pseudopregnancies.

\section{Discussion}

Our results show that, in brown hares, the age at the first ovulation depends on the season of birth and corresponds to an enhanced secretion of LH after LHRH. Among the young females born in 
January-February (group I), a low proportion ovulated in response to LHRH and developed a pseudopregnancy from June, at the age of 4 months; those not able to ovulate would breed in the next January, at the age of 11-12 months. The young doe hares born after March (group II and III) ovulated at the beginning of the next breeding season, between the ages of 5 and 9 months.

These results on the age at first ovulation confirm those concerning the age at first pregnancy in wild and captive females (Flux, 1967; Lincoln 1974; D. Pépin, personal communication; Louzis, 1976). Similarly, the young bucks born before May can reach puberty when 3 months old, whereas those born from May to July display a seasonally delayed puberty until next January (6-8 months) (Lincoln \& McKinnon, 1976; Meunier \& Martinet, 1986).

In a closely related species, the young doe rabbit, the sexual receptivity appears when females are 3 months old, but $80 \%$ of females can ovulate when only 4 months old (Hulot et al., 1982; de Turckheim et al., 1983). As in hares, the season influences the age at puberty: the females born in summer reach puberty later than the others (Kamwanja \& Hauser, 1983), but there are no more precise data. Furthermore, in young rabbits, there is a progressive increase in both basal and LHRH-stimulated LH secretion with age, and, from the age of 4 months, the pituitary response can be sufficient to induce ovulation (Berger et al., 1981; Blanc et al., 1982; Younglaï, 1986; Younglaï et al., 1989).

The present results show that, in young doe hares, the pituitary response to LHRH increased gradually from the age of 3 months, in groups I and III, and from the age of 9 months in group II. The ovarian response to $\mathrm{LH}$, corresponding to the acute progesterone secretion and originating probably from interstitial tissue (Briot, 1986), increased simultaneously. So there is a maturation of the pituitary-ovarian axis between 3 and 6 months and the prepubertal stage could then be a consequence of a lack of gonadotrophin synthesis due either to a primary deficit in the release of endogenous LHRH, as in primates (Plant, 1988), or to a high sensitivity to oestradiol feedback, as in lambs (Foster, 1988) or ferrets (Ryan, 1984; Ryan \& Robinson, 1987).

In seasonal breeders, sexual maturity will occur only when internal and external cues indicate that both body size and season are favourable for initiating a pregnancy (Foster, 1988). In brown hares, whatever the photoperiod, the mature body size is almost reached at 4 months of age, thus allowing puberty to occur (Lincoln, 1974; Meunier \& Martinet, 1986). In adult females, the seasonal conditions allowing reproduction occur during increasing and long daylengths (January to September) and are related to a large increase in both basal and LHRH-stimulated LH secretion (Caillol et al., 1986). Furthermore, there is a direct central effect of season on the regulation of LH concentrations, with high values observed from December to August in long-term ovariectomized doe hares (Caillol et al., 1990). Thus, in brown hares, the body weight and seasonal conditions required to reach puberty are present simultaneously either from May to August, under long daylengths, for females born at the beginning of the breeding season, or in January for the others.

However, in group I at the end of the first breeding season, the secretion of LH and progesterone induced by LHRH was significantly higher in females that could ovulate than in nonovulating females, but remained lower than in adults (Caillol et al., 1986), suggesting a relative immaturity of the pituitary, perhaps due to decreasing daylengths after the summer solstice.

Females born in April (group II) reached their adult size in August, at the end of the breeding season; the secretion of $\mathrm{LH}$ and progesterone remained very low in July-August and during the following anoestrus as in adult females (Caillol et al., 1986). The pituitary and ovarian responses to LHRH increased in January, at the age of 9 months, thus these females displayed a seasonally delayed puberty.

The increase of pituitary and ovarian responses to LHRH occurred earlier in group III females than in the other groups ( 4 months), and a large biphasic pattern of LH release similar to that of the adult (Caillol et al., 1986) was observed at the age of 5 months with $80 \%$ of ovulating females. The most favourable conditions for the hare to reach puberty early would then be a period of short decreasing daylengths during the autumn, followed by increasing daylengths after the winter solstice. This increase in daylengths seems insufficient on its own to allow full sexual maturity to occur, 
as suggested by the low pituitary response of group I in May-August (even if $10-20 \%$ of females can ovulate after L.HRH). This hypothesis is confirmed by the results obtained in ewes: the lamb requires exposure to alternate photoperiods to begin reproductive cycles at the appropriate age, and long days must precede the short days during which puberty is attained (Foster et al., 1986; Foster, 1988).

Another possibility is that the low pituitary response of group I young hares in July-August is due to the suppressive effects of decreasing daylengths after the summer solstice, as already shown in rabbits: in females, emission of a pheromone by the nipples occurs under long daylengths; a decrease in daylength of just $1 \mathrm{~h}$ is sufficient to induce marked diminution within 2 or 3 weeks in the level of pheromone emission, number of successful matings and litter size (Hudson \& Distel, 1990). In male rabbits, the testis size regressed after the summer solstice, and daylength primarily affects a hypothalamic component of the reproductive system (Boyd, 1985, 1987). However, in hares, this suggestion seems less probable since, in adults, the reproductive axis is still fully active in August.

The authors thank A. Solari for help with statistics, M. Carpentier and G. Oxaran for skilful care of the animals, G. D. Niswender (College of Veterinary Medicine and Biomedical Sciences, Dept of Physiology and Biophysics, Colorado State University, Fort Collins, CO 80523, USA) for the LH GDN 15 antiserum, L. E. Reichert (Dept of Biochemistry, Albany Medical College, Albany, NY 12208, USA) for the ovine LH and canine pituitary standard and R. Scholler for facilities to perform hormone assays in the laboratories of the Fondation de Recherche en Hormonologie.

\section{References}

Berger, M., Jean-Faucher, C., de Turckheim, M., Veyssière, G. \& Jean, C. (1981) Pituitary luteinizing hormone and follicle-stimulating hormone from birth to adulthood in male rabbit. Hormone Research 15, 242-251.

Blanc, M., Hulot, F. \& Moret, B. (1982) Sécrétion des hormones gonadotropes au cours de la puberté chez des lapines de race californienne et néo-zélandaise. In Troisièmes Journées de la Recherche Cunicole en France, pp. 11.1-11.8. INRA-ITAVI, Paris.

Boyd, I.L. (1985) Effect of photoperiod and melatonin on testis development and regression in wild European rabbits (Oryctolagus cuniculus). Biology of Reproduction 33, 21-29.

Boyd, I.L. (1987) Gonadotrophin secretion and pituitary responsiveness to LHRH in castrated and intact male rabbits exposed to different photoperiods. Journal of Reproduction and Fertility 79, 627-633.

Briot, P. (1986) Etudes in vivo et in vitro de la biosynthèse des oestrogènes chez la hase (Lepus europaeus). Thèse de doctorat de troisième cycle, Université de Paris VI.

Caillol, M. \& Martinet, L. (1976) Preliminary results on plasma progesterone levels during pregnancy and superfoetation in the hare, Lepus europaeus. Journal of Reproduction and Fertility 46, 61-64.

Caillol, M., Meunier, M., Mondain-Monval, M. \& Simon, P. (1986) Seasonal variations in the pituitary response to LHRH in the brown hare. Journal of Reproduction and Fertility 78, 479-486.

Caillol, M., Mondain-Monval, M., Meunier, M. \& McNeilly, A.S. (1990) Effect of ovariectomy at two periods of the year on LH and FSH basal concentrations and pituitary response to LHRH in the brown hare (Lepus europaeus). Journal of Reproduction and Fertility 88, 533-542. de Turckheim, M., Berger, M., Jean-Faucher, C., Veyssière, G. \& Jean, C. (1983) Changes in ovarian oestrogens and in plasma gonadotrophins in female rabbits from birth to adulthood. Acta Endocrinologica 103, 125-130.

Flux, J.E.C. (1967) Reproduction and body weights of the hare (Lepus europaeus Pallas) in New-Zealand. New-Zealand Journal of Science 10, 357-401.

Foster, D.L. (1988) Puberty in the female sheep. In The Physiology of Reproduction, pp. 1739-1762. Eds E. Knobil, J. Neill, L. Ewing, G. Greenwald, C. Markert \& D. Pfaff. Raven Press, New York.

Foster, D.L., Karsch, F.J., Olster, D.H., Ryan, K.D. \& Yellon, S.M. (1986) Determinants of puberty in a seasonal breeder. Recent Progress in Hormone Research 42, 331-384.

Hewson, R. (1964) Reproduction in the brown hare and the mountain hare in north-east Scotland. The Scottish Naturalist 71, 81-89.

Hudson, R. \& Distel, H. (1990) Sensitivity of female rabbits to changes in photoperiod as measured by pheromone emission. Journal of Comparative Physiology $A$ 167, 225-230.

Hulot, F., Mariana, J.C. \& Lebas, F. (1982) L'établissement de la puberté chez la lapine (folliculogénèse et ovulation). Effet du rationnement alimentaire. Reproduction, Nutrition, Developpement 22, 439-453.

Kamwanja, L.A. \& Hauser, E.R. (1983) The influence of photoperiod on the onset of puberty in the female rabbit. Journal of Animal Science 56, 1370-1375.

Lincoln, G.A. (1974) Reproduction and March madness in the brown hare, Lepus europaeus. Journal of Zoology, London 174, 1-14.

Lincoln, G.A. \& McKinnon, P.C.B. (1976) A study of seasonally delayed puberty in the male hare Lepus 
europaeus. Journal of Reproduction and Fertility 46, 123-128.

Louzis, C. (1976) Contribution à l'étude de la reproduction du lievre européen (Lepus europaeus Pallas) en captivité étroite. Recueil de Médecine Vétérinaire 152, 543-546.

Martinet, L., Llegouis, J.J. \& Moret, B. (1970) Quelques observations sur la reproduction du lièvre (Lepus europaeus) en captivité. Annales de Biologie Animale, Biochimie, Biophysique 10, 195-202.

Meunier, M. \& Martinet, L. (1986) Role of different photoperiodic treatments on the growth of the testis in juvenile and adult brown hares (Lepus europaeus Pallas). In Endocrine regulations as adaptive mechanisms to the environment, pp. 155-159. Eds I. Assenmacher \& J. Boissin. CNRS, Paris.

Mondain-Monval, M., Caillol, M. \& Meunier, M. (1985) Heterologous radioimmunoassay of LH in two seasonally breeding animals: hare (Lepus europaeus) and mink (Mustela vison). Canadian Journal of Zoology 63, 1339-1344.

Plant, T. (1988) Puberty in Primates. In The Physiology of Reproduction, pp. 1763-1788. Eds E. Knobil,
J. Neill, L. Ewing, G. Greenwald, C. Markert \& D. Pfaff. Raven Press, New York.

Raczynski, J. (1964) Studies on the European Hare. V. Reproduction. Acta Theriologica 9, 305-352.

Ryan, K.D. (1984) Hormonal correlates of photoperiodinduced puberty in a reflex ovulator, the female ferret (Mustela furo). Biology of Reproduction 31, 925-935.

Ryan, K.D. \& Robinson, S.L. (1987) A study of spontaneous sexual maturation of the female ferret. Biology of Reproduction 36, 333-339.

SAS (1987) SAS/STAT Guide for Personal Computers. SAS Institute Inc., Cory, NC 27512, USA.

Younglai, E.V. (1986) Age-related changes in the concentrations of gonadotropins and cholesterol in the female rabbit. Journal of Endocrinology 109, 287-290.

Younglaï, E.V., Thompson, N. \& Foster, W. (1989) Effects of in vivo administration of $\mathrm{GnRH}$ on the release of gonadotrophins in the female rabbit. Journal of Reproduction and Fertility 85, 325-329.

Received 11 November 1991 